\title{
ISU-ISU KRITIS LINGKUNGAN DAN PERSPEKTIF GLOBAL
}

\author{
Vania Zulfa ${ }^{1}$, Milson Max ${ }^{1}$, Iskar Hukum ${ }^{1}$, Irfan Ilyas $^{1}$ \\ Pascasarjana Universitas Negeri Jakarta, \\ Komplek Universitas Negeri Jakarta Gedung M. Hatta Jl. Rawamangun Muka, Jakarta Timur, \\ Indonesia 13220 \\ Email: vaniazulfa@gmail.com
}

\begin{abstract}
Students of the Faculty of Mathematics and Natural Sciences as part of today's society as well as part of the next generation are expected to have an in-depth understanding of environmental and ecopedagogic environmental issues because they have a supportive background to form good environmental management. With an understanding of the critical issues on the environment and the concept of ecopedagogy it is expected to open the student's perspective on how to utilize natural resources wisely so as not to cause sustained damage. The purpose of this research is to identify the relation of understanding of environmental critical issues and ecopedagogic concept with global perspective on UNJ MIPA faculty students. This research was conducted in December 2016-January 2017 at State University of Jakarta. The method used is quantitative through correlational studies. Sampling was done by simple random sampling as many as 30 students of MIPA UNJ faculty. Having tested the prerequisite, the research data is normally distributed and homogeneous. The multiple regression model is $\hat{Y}=74,650-0,079 X 1+0,048 X 2$. The correlation coefficient $x 1$ with y is -0.177 whereas the correlation coefficient $x 2$ with $y$ is 0.115 with the coefficient of determination 0,013 . So understanding the concept of ecopedagogic gives $1.3 \%$ contribution to global perspective. The result of this research is a negative relationship between understanding environmental critical issues with global perspective and there is a positive relationship between understanding the concept of ecopedagogic with global perspective. Therefore, by enhancing the understanding of the concept of ecopedagogic can improve the global perspective so that the environment will be maintained both for the present and for the future
\end{abstract}

Key words: Critical environmental issues, ecopedagogik, global perspective 


\section{PENDAHULUAN}

Isu-isu lingkungan yang marak diperbincangkan khususnya pada abad 21 ini menjadi topik yang sangat menyorot perhatian. Dibutuhkan manusia-manusia yang memiliki rasa tanggung jawab dan rasa saling membutuhkan terhadap lingkungan untuk mengatasi permasalahan lingkungan yang cukup kompleks ini. Pengelolaan yang bijaksana juga dapat menjadi salah satu jalan keluar untuk meminimalisir kerusakan lingkungan.

Pengelolaan lingkungan secara bijaksana menuntut adanya pengetahuan yang cukup tentang lingkungan dan akibat yang dapat timbul karena gangguan manusia. Oleh karena itu, konsep pemahaman isu-isi kritis lingkungan harus dipahami secara mendalam. Pendidikan lingkungan sebagai mata kuliah yang dapat diambil oleh mahasiwa fakultas MIPA diharapkan dapat mengambil peran penting untuk membentuk karakter mahasiswa khususnya fakultas MIPA untuk mengelola lingkungan dengan bijaksana.

Mahasiswa Fakultas MIPA dipandang sebagai mahasiswa yang dekat dengan istilah-istilah lingkungan, memiliki peran penting dalam menjaga kelesatarian lingkungan. Pemahaman mengenai isu-isu kritis lingkungan dapat menjadi salah satu upaya untuk mengubah perilaku mahasiswa sehingga terbentuk mahasiswa yang memiliki sikap peduli lingkungan untukmemperbaiki kondisi lingkungan kelak. Pengetahuan, keterampilan dan kesadaran mahasiswa tentang nilai-nilai lingkungan dan isu permasalahan lingkungan pada akhirnya dapat menggerakkan mahasiswa untuk berperan aktif dalam upaya pelestarian dan keselamatan lingkungan. Maka pendidikan lingkungan merupakan tumpuan bagi pengelolaan sumber daya sebagai sumber bagi kehidupan sekarang dan di masa yang akan datang.

Sebagai mahasiswa yang diduga memiliki sikap positif terhadap lingkungan, mahasiswa fakultas MIPA diharapkan memiliki pemahaman isuisu kritis lingkungan yang tinggi terhadap perspektif global. Seseorang yang memiliki pemahaman mendalam mengenai isu-isu kritis lingkungan artinya orang tersebut telah memiliki cara pandang yang global dan diharapkan dapat membawa dampak positif untuk lingkungan. Oleh karena itu sangat dibutuhkan penelitian yang berkaitan dengan hubungan pemahaman isu-isu kritis lingkungan dengan 
perspektif global untuk mengidentifikasi

hubungan antar keduanya.

Di Indonesia, topik masalah lingkungan hidup mulai diperbincangkan sejak diselenggarakannya Seminar Pengelolaan Lingkungan Hidup dan Pembangunan Nasional oleh Universitas Pajajaran Bandung pada tanggal 15-18 Mei 1972 (Aziz, 2011). Faktor terpenting dalam permasalahan lingkungan adalah besarnya populasi manusia (laju pertumbuhan penduduk). Pertumbuhan penduduk yang pesat menimbulkan tantangan yang dicoba diatasi dengan pembangunan dan industrialisasi. Namun industrialisasi di samping mempercepat persediaan segala kebutuhan hidup manusia juga memberi dampak negatif terhadap manusia akibat terjadinya pencemaran lingkungan.

Kondisi lingkungan secara perlahan-lahan telah tercemar. Dampaknya berupa kerusakan atau kehancuran sumber-sumber genetika tanaman, dan sumber-sumber organisme hidup yang bahkan diantaranya mungkin merupakan suatu kebutuhan penting bagi manusiayang jika secara terus menerus memburuk dapat memperburuk kesejahteraan hidup manusia dan juga mahluk hidup lainnya.
Dampak lainnya tidak hanya menimbulkan ancaman terhadap kelestarian sumber daya alam, akan tetapi juga menimbulkan proses berantai yang akan membuat kerusakan pada lingkungan hidup.

Untuk memelihara kelestarian lingkungan ini setiap pengelolaan harus dilakukan secara bijaksana. Pengelolaan yang bijaksana menuntut adanya pengetahuan yang cukup tentang isu-isu lingkungan yang ada dan akibat yang dapat timbul karena gangguan manusia (Zoer'aini, 2012). Pengelolaan yang bijaksana juga menuntut kesadaran akan tanggung jawab manusia terhadap kelangsungan generasi mendatang (Soedjiran, M.A., \& Aprilani, 1984).

Peningkatan kesadaran manusia akan lingkungan bertujuan untuk meningkatkan pengetahuan, keterampilan dan kesadaran mayarakat tentang nilai-nilai lingkungan dan isu permasalahan lingkungan yang pada akhirnya dapat menggerakkan masyarakat untuk berperan aktif dalam upaya pelestarian dan keselamatan lingkungan untuk kepentingan generasi sekarang dan yang akan datang.

Mahasiswa Fakultas Matematika dan Ilmu Pengetahuan Alam (MIPA) Universitas Negeri Jakarta merupakan salah satu miniatur masyarakat yang 
diharapkan memiliki peran penting untuk mengelola lingkungan di masa yang akan datang. Mahasiswa Fakultas MIPA sebagai bagian dari masyarakat sekarang dan juga merupakan bagian dari generasi yang akan datang diharapkan memiliki pemahaman mendalam mengenai isu-isu kritis lingkungan karena memiliki latar belakang yang mendukung untuk membentuk pengelolaan lingkungan yang baik. Dengan pemahaman mengenai isu-isu kritis lingkungan diharapkan dapat membuka cakrawala pandang mahasiswa tentang bagaimana memanfaatkan sumber daya alam dengan bijaksana sehingga tidak menimbulkan kerusakan yang berkelanjutan(Soedjiran, M.A., \& Aprilani, 1984).

Penanaman pemahaman isu-isu kritis lingkungan di tingkat universitas umumnya diterapkan melalui mata kuliah pendidikan lingkungan hidup. Pemahaman mengenai isu-isu kritis lingkungan memiliki satu tujuan yaitu agar mahasiswa memiliki pandangan yang bersifat menyeluruh dalam melihat permasalahan lingkungan yang ada sehingga diharapkan dapat membantu menumbuhkan rasa peduli terhadap lingkungan dan rasa tanggung jawab atas lingkungan yang mereka tinggali saat ini agar kelak tetap dapat dinikmati oleh generasi berikutnya.

Sedangkan perspektif merupakan cara pandang atau cara berpikir seseorang tentang suatu obyek. Perspektif global adalah suatu cara pandang dan cara berpikir terhadap suatu masalah, kejadian atau kegiatan dari sudut kepentingan global, yaitu dari sisi kepentingan dunia atau internasional. Oleh karena itu, sikap dan perbuatan kita juga diarahkan untuk kepentingan global. Dengan kata lain, perspektif global adalah suatu pandangan yang timbul akibat suatu kesadaran bahwa hidup ini adalah untuk kepentingan global yang lebih luas(Wihardit, 1999).

Hanvey (An Attainable Global Perspective, 2011) dalam bukunya yang sangat terkenal “An Attainable Global Perspective" menyebutkan 5 dimensi dari perspektif global sebagai berikut:

\section{Perspective consciousness}

Kesadaran dan penghargaan terhadap adanya berbagai macam pendapat yang berbeda-beda di dunia ini.

2. State of planet awareness

Adanya pengertian yang mendalam terhadap isu-isu dan peristiwaperistiwa global.

3. Cross-cultural awareness 
Adanya kesepakatan yang bisa diterima secara umum dalam membuat karakteristik budayabudaya yang ada di dunia ini, yaitu bahwa sekalipun ada perbedaanperbedaan dalam budaya, namun ada banyak kesamaan yang dimiliki.

4. Systemic awareness

Mengetahui akan sistem-sistem yang ada di alam, sehingga mulai mengenal kompleksnya sistem internasional, di mana aktor-aktor negara dan aktor-aktor non-negara saling mempengaruhi dalam berbagai macam isu yang terjadi di kawasan-kawasan yang ada di dunia ini.

\section{Options for participation}

Mengetahui strategi-strategi yang tepat sehingga mampu berpartisipasi dengan baik dalam menghadapi isuisu yang terjadi di tingkat lokal, nasional hingga internasional.

Dengan mempelajari perspektif global maka diharapkan akan:

1. Meningkatkan wawasan dan kesadaranpara pendidik dan peser ta didik bahwa kita bukan hanya penghuni satu daerah, tetapi mempunyai ketergantungan dengan orang lain di belahan bumi yang lain.
2. Menambah dan memperluas pengetahuan kita tentang dunia, sehingga dapat megikuti perkembangan dunia dalam berbagai aspek terutama perkembangan iptek.

3. Mengkondisikan para mahasiswa untuk berpikir integral bukan general, sehingga suatu gejala atau masalah dapat ditanggulangi dari berbagai aspek.

4. Melatih kepekaan dan kepedulian mahasiswa terhadap perkembangan dunia dengan segala aspeknya.

Tujuan diberikannya perspektif global menurut Marryfield, 1977 adalah :

1. Mendorong mahasiswa untuk mempelajari lebih banyak tentang materi dan masalah yang berkaitan dengan masalah global.

2. Mendorong para guru untuk mempelajari masalah yang berkaitan dengan masalah lintas budaya.

3. Mengembangkan dan memahami makna perspektif global baik dalam kehidupan sehari-hari maupun pengembangan profesinya.

Berkaitan dengan masalah global, Merryfield M. mengemukakan pokokpokok masalah global, diantaranya penduduk dan keluarga berencana (population and family 
planning), hak rakyat menentukan pemerintahan sendiri (selfdetermination), pembangunan (develo pment), hak asasi manusia (human right), emigrasi, imigrasi dan pengungsian (emigration, immigratio $\mathrm{n}$ and refugees), kepemilikan bersama secara global (the global commnos), lingkungan hidup dan sumber daya alam (environment and natural resources), persebaran kemakmuran, teknologi informasi, sumber daya alam, kelaparan dan bahan pangan, perdamaian dan keamanan, prasangka dan diskriminasi.

Sedangkan pemahaman terhadap isu-isu kritis lingkungan yang dimaksud adalah penilaian atau pendapat seseorang dalam menaggapi masalah kritis lingkungan sehingga mereka dapat merespon dengan indikator: 1) menjelaskan, 2) menganalisis, dan 3) mengkritisi masalah tersebut. (Kahn, 2010). Menurut Bloom(1971) "Here we are using the tern "comprehension" to include those objectives, behaviors, or responses which represent an understanding of the literal message contained in a communication." Artinya: Disini menggunakan pengertian pemahaman mencakup tujuan, tingkah laku, atau tanggapan (menjelaskan, menganalisis dan mengkritisi) mencerminkan sesuatu pemahaman pesan tertulis yang termuat dalam satu komunikasi. Kemampuan dalam memahami suatu objek umumnya mendapat penekanan dalam proses belajar mengajar. Oleh sebab itu siswa dituntut memahami atau mengerti apa yang diajarkan, mengetahui apa yang sedang dikomunikasikan dan dapat memanfaatkan isinya tanpa keharusan menghubungkan dengan hal-hal yang lain.

Saat ini masalah lingkungan cukup sering diperbincangkan. Sebagaimana telah diketahui bahwa lapisan ozon kini semakin menipis. Dengan terus menipisnya lapisan ozon, sangat dikhawatirkan bila lapisan ini tidak ada atau menghilang sama sekali dari alam semesta ini. Tanpa lapisan ozon sangat banyak akibat negatif yang akan menimpa makhluk hidup di muka bumi ini (Effendi, 2001).

Masalah global lainnya yang kini menjadi isu kritis lingkungan diantaranya pertumbuhan penduduk dunia yang amat pesat (Resosoedarmo Soedjiran, 1984). Pertumbuhan penduduk ini juga akan 
berdampak pada meningkatnya kebutuhan produksi pangan. Saat ini Indonesia masih sangat bergantung pada sumber energi minyak bumi. Penggunaan minyak dari sisi lingkungan, dan lebih spesifiknya sisi komposisi udara di atmosfir, berarti peningkatan gas karbon dioksiida (CO2). Gas ini, bersama lima jenis gas lain diketahui menjadi penyebab terjadinya efek pemanasan global (Hermawan, 2017).

Diperkirakan diantara tahun 1990-2100 akan terjadi kenaikan ratarata suhu global sekitar 1,4 sampai 5,8 derajat celsius. Akibatnya akan terjadi kenaikan rata-rata permukaan air laut disebabkan mencairnya gunung-gunung es di kutub. Banyak kawasan di dunia akan terendam air laut. Akan terjadi perubahan iklim global. Hujan dan banjir akan meningkat. Wabah beberapa penyakit akan meningkat pula. Produksi tumbuhan pangan pun terganggu

Atas dasar pemikiran tersebut diduga terdapat hubungan positif antara pemahaman isu-isu kritis lingkungan dengan perspektif global. Dengan kata lain, makin tinggi pemahaman isu-isu kritis lingkungan makin tinggi perspektifglobal mahasiswa dalam melihat permasalahan lingkungan. Oleh karena itu sangat penting untuk diketahui hubungan pemahaman isuisu kritis lingkungan dengan perspektif global.

Berikut ini beberapa manfaat dari pemahaman perspektif global yang mendalam:

1. Meningkatkan wawasan dan kesadaran bahwa kita bukan hanya penghuni satu daerah, tetapi mempunyai ketergantungan dengan orang lain di belahan bumi yang lain. Oleh karena itu sikap kita harus mencerminkan "sikap ketergantungan" tersebut (Suwasono, 1994).

2. Menambah dan memperluas pengetahuan kita tentang dunia, sehingga dapat mengikuti perkembangan dunia dalam berbagai aspek terutama perkembangan iptek.

3. Mengkondisikan para mahasiswa untuk berpikir integral bukan general, sehingga suatu gejala atau masalah dapat ditanggulangi dari berbagai aspek.

4. Melatih kepekaan dan kepedulian mahasiswa terhadap perkembangan dunia dengan segala aspeknya. 
Sehingga dengan meningkatkan pemahaman mengenai isu-isu kritis lingkungan maka perspektif global pun akan meningkat.

\section{METODOLOGI}

Penelitian ini dilakukan di Universitas Negeri Jakarta dengan menggunakan metode kuantitatif melalui studi korelasional. Adapun yang menjadi variabel bebas adalah pemahaman isu-isu kritis lingkungan (X) dan variabel terikatnya adalah perspektif global (Y).

$$
\text { Populasi target dalam }
$$
penelitian ini adalah seluruh mahasiswa Universitas Negeri Jakarta. Populasi terjangkau dalam penelitian ini adalah Mahasiswa Universitas Negeri Jakarta Fakultas MIPA. Fakultas ini dipilih karena fakultas ini memiliki latar belakang yang kuat mengenai pemahaman isuisu kritis lingkungandan perspektif global. Adapun sampelnya diambil dengan cara simple random sampling. Sampel yang diambil dalam penelitian ini sebanyak 30 mahasiswa.

Teknik pengumpulan data dalam penelitian ini adalah dengan menggunakan kuesioner isu-isu kritis lingkungan dan kuesioner perspektif global yang dibuat dalam bentuk google form dan disebarkan secara online melalui media sosial.

\section{HASIL DAN PEMBAHASAN}

Hasil yang diperoleh berupa skor perspektif global dan skor pemahaman isu-isu kritis lingkungan dari 30 responden dengan statistik deskriptif seperti yang terdapat pada tabel 1 berikut ini:

Tabel 1.

Statistik Deskriptif

Descriptive Statistics

\begin{tabular}{|l|r|r|r|r|r|}
\hline & \multicolumn{1}{|c|}{ N } & Mnimum & Maximum & Mean & Std. Deviation \\
\hline$X$ & 30 & 40 & 87 & 60.73 & 11.893 \\
$Y$ & 30 & 63 & 85 & 72.40 & 4.775 \\
Valid (Iiswise) & 30 & & & & \\
\hline
\end{tabular}

\section{a. Skor Perspektif Global}

Hasil yang diperoleh dari instrumen perspektif global memilki skor terendah 63 dan skor tertinggi 85 . Rata-rata skor perspektif global adalah 72,40. frekuensi tertinggi terdapat pada kelas interval 70-76 yaitu sebanyak 19 responden.Interval kelas yang memiliki frekuensi yang paling sedikit adalah 8490 yaitu sebanyak 1 responden. 
Adapun distribusi frekuensi skor perspektif global ditunjukkan pada gambar 1 berikut ini:

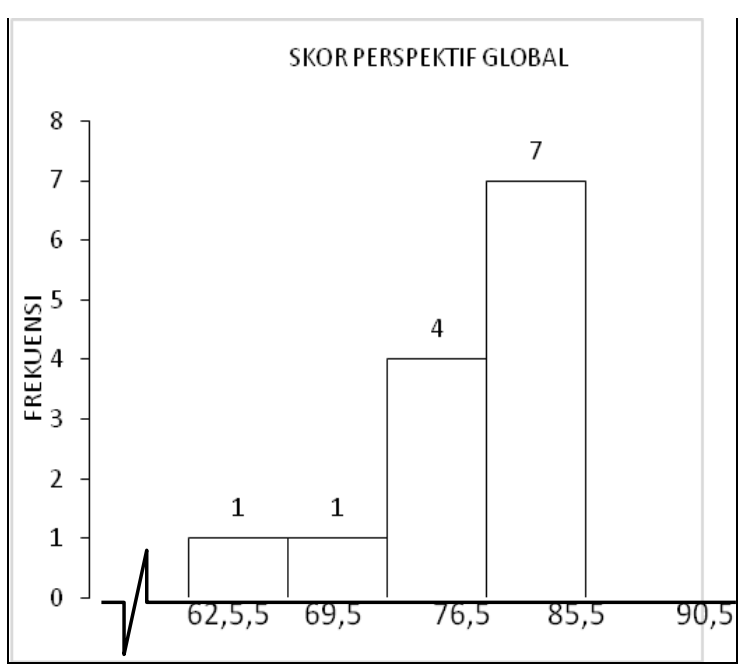

Gambar 1. Grafik Histogram Distribusi Frekuensi Skor Perspektif Global

\section{b. Skor Pemahaman Isu-isu Kritis}

\section{Lingkungan}

Hasil yang diperoleh dari instrumen pemahaman isu-isu kritis lingkungan memiliki skor terendah 40 dan skor tertinggi 87. Rata-rata skor pemahaman isu-isu kritis lingkungan adalah 60,73. frekuensi tertinggi terdapat pada kelas interval 65-69 yaitu sebanyak 35 responden.Interval kelas yang memiliki frekuensi yang paling sedikit adalah 45-49 yaitu 5 responden. Distribusi frekuensi skor pemahaman isu-isu kritis lingkungan terdapat pada gambar 2 berikut ini:

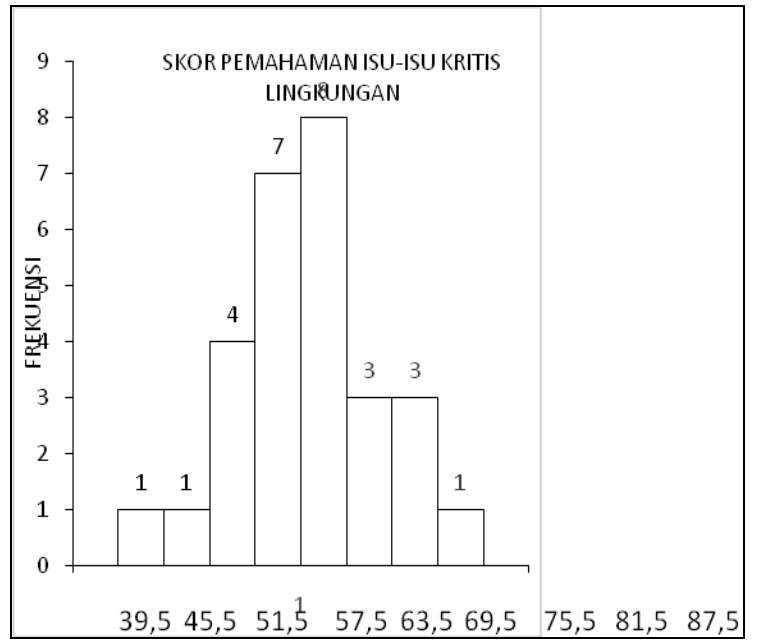

Gambar 2.

Histogram distribusi frekuensi skor pemahaman isu-isu kritis lingkungan

Hasil penelitian yang telah diuji prasyarat kemudian diuji dengan analisis model regresi dan linearitas. Uji ini dilakukan untuk mengetahui apakah model regresi signifikan atau tidak dan untuk mengetahui apakah data yang diperoleh linier atau tidak.

\section{Persamaan Regresi (Y terhadap X)}

Berdasarkan uji regresi didapatkan model regresi perspektif global terhadap pemahaman isu-isu kritis lingkunganlinier pada $\hat{Y}=75,636$ 0,0558 X. Model regresi pemahaman isu-isu kritis lingkungan dengan perspektif global ditunjukkan pada tabel 3 dan gambar 4 berikut ini:

Tabel 3.Model regresi Y terhadap X 


\begin{tabular}{|c|c|c|c|c|c|c|}
\hline \multicolumn{7}{|c|}{ Coefficients $^{\mathrm{a}}$} \\
\hline \multirow[b]{2}{*}{ Model } & & \multicolumn{2}{|c|}{ Unstandardized Coefficients } & \multirow{2}{*}{$\begin{array}{l}\text { Standardized } \\
\text { Coefficients } \\
\text { Beta } \\
\end{array}$} & \multirow[b]{2}{*}{$t$} & \multirow[b]{2}{*}{ Sig. } \\
\hline & & B & Std. Error & & & \\
\hline 1 & (Constant) & 75.862 & 4.645 & & 16.331 & .000 \\
\hline & $x$ & .057 & .075 & 142 & -.759 & .454 \\
\hline
\end{tabular}

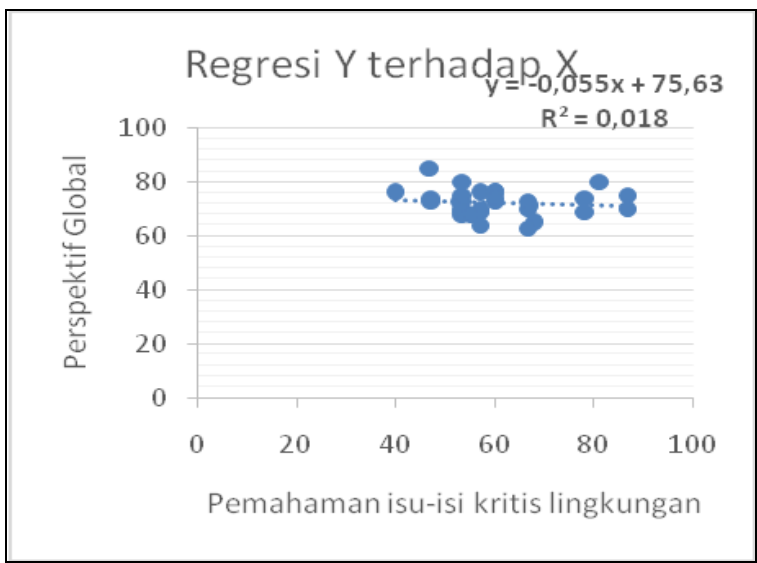

Gambar 4.Model regresi Y terhadap X

\section{Uji Signifikansi Regresi Y terhadap X}

Berdasarkan uji signifikansi didapatkan hasil signifikansi 0,454 lebih besar dari alpha 0,05. Oleh karena itu, model regresi ini tidak signifikan. Artinya tidak dapat digunakan untuk memprediksi variabel Y terhadap X.

Tabel 4.Tabel ANAVA Uji Signifikansi

\begin{tabular}{|c|c|c|c|c|c|c|}
\hline \multicolumn{7}{|c|}{ ANOVA $^{b}$} \\
\hline Model & & $\begin{array}{l}\text { Sum of } \\
\text { Squares }\end{array}$ & df & Mean Square & $F$ & Sig. \\
\hline 1 & Regression & 13.326 & 1 & 13.326 & .576 & $.454^{\mathrm{a}}$ \\
\hline & Residual & 647.874 & 28 & 23.138 & & \\
\hline & Total & 661.200 & 29 & & & \\
\hline
\end{tabular}

a. Predictors: (Constant), $X$

b. DependentVariable: $Y$

\section{Korelasi Perspektif Global terhadap} Isu-isu kritis lingkungan

Adapun korelasi perspektif global terhadap isu-isu lingkungan terdapat pada tabel 4 berikut ini:

Tabel 4. Model korelasi Y terhadap X

\begin{tabular}{|} 
Correlations \\
\begin{tabular}{|rl|r|r|}
\hline & & \multicolumn{1}{c|}{$\mathrm{X}$} & \multicolumn{1}{c|}{$\mathrm{Y}$} \\
\hline $\mathrm{X}$ & Pearson Correlation & 1 & -.142 \\
& Sig. (2-tailed) & & .454 \\
& $\mathrm{~N}$ & 30 & 30 \\
\hline $\mathrm{Y}$ & Pearson Correlation & -.142 & 1 \\
& Sig. (2-tailed) & .454 & \\
$\mathrm{~N}$ & 30 & 30 \\
\hline
\end{tabular}
\end{tabular}

Berdasarkan hasil uji korelasi $\mathrm{X}$ dan Y didapatkan bahwa korelasi X dan Y bernilai negatif $(-0,142)$ yang artinya kedua variabel mempunyai hubungan terbalik. Artinya jika nilai variabel $\mathrm{X} 1$ tinggi, maka nilai variabel $\mathrm{Y}$ akan menjadi rendah. Hasil uji signifikansi juga menunjukkan bahwa signifikansi $(0,454)$ lebih besar dari nilai alpha 0,05. Oleh karena itu, dapat disimpulkan tidak terdapat hubungan yang signifikan antara pemahaman isu-isu kritis lingkungan (X) dengan perspektif global (Y).

Dari hasil penelitian didapatkan pemahaman isu-isu kritis lingkungan 
memiliki korelasi negatif dengan perspektif global.

Berdasarkan indikator yang digunakan untuk mengukur pemahaman isu-isu kritis lingkungan ; 1) menafsirkan, 2) memberi contoh, 3) membandingkan dan 4) menyimpulkan masalah, skor tertinggi terdapat pada indikator pertama yaitu menafsirkan. Sebanyak $40 \%$ responden menjawab benar pada butir instrumen yang mengukur penafsiran atau definisi.

Sedangkan untuk indikator lainnya, khususnya indikator ke empat memiliki skor yang paling rendah. Hanya $10 \%$ responden yang menjawab indikator menyimpulkan masalah dengan benar. Berdasarkan analisis tersebut dapat disimpulkan bahwa banyak responden yang memahami isu-isu lingkungan hanya di permukaannya saja. Sedangkan untuk memberikan contoh terhadap isu-isu lingkungan, membandinkan dengan isuisu lingkungan lainnya, dan menyimpulkan masalah lingkungan masih sangat minim.

Hal ini dapat disebabkan oleh beberapa faktor diantaranya:

a. Kurangnya pemahaman mengenai pentingnya memiliki pengetahuan yang luas mengenai isu-isu kritis lingkungan b. Kurang terbukanya cara pandang, sehingga cenderung melihat isu-isu lingkungan hanya sebagian kecil lingkungan yang ditinggalinya saja

Semua hasil uji menunjukan tidak terdapat hubungan yang signifikan, baik pengujian regresi maupun korelasi. Hal ini dapat terjadi karena sampel yang diambil terlalu sedikit sehingga menyebabkan hasil uji yang tidak signifikan. Dari kedua isntrumen, instrumen perspektif global memiliki skor terntinggi. Hal ini dikarenakan perspektif global merupakan bentuk sifat. Instrumen yang dibuat pun memiliki petunjuk pengisian yang pilihan yang sangat mudah dan jelas untuk diisi.

Perspektif global menjadi penjaga stabilitas dan pengontrol faktor luar yang sangat kuat. Oleh karena itu, peningkatan kerja sama dengan negara lain dalam segala bidang perlu ditingkatkan. Negara harus bersifat terbuka, karena kerja sama dalam berbagai bidang menuntut adanya komitmen yang tinggi. Negara harus beradaptasi dengan sistem yang terus berubah, aktif mengikuti dan mengadakan perubahan. 


\section{KESIMPULAN}

Kesimpulan dalam penelitian ini adalah tidak terdapat hubungan yang signifikan antara pemahaman isu-isu kritis lingkungan dengan perspektif global.

\section{DAFTAR PUSTAKA}

Aziz, H. A. (2011). Pendidikan Karakter. Jakarta: Al-Mawardi Prima.

Bloom, B. (1971). Taxonomy of Educational Objectives, Handbook I Cognitive Domain. Michigan: Edward Bros.

Effendi. (2001). Pemanasan Global. Jakarta: Erlangga.

Hanvey, R. G. (2011). An Attainable Global Perspective (Volume XXI, No. 3 ed.). USA: Center for War/Peace Studies.

Hermawan. (2017, January 05). Upaya pencegahan dampak global warming. $\quad \mathrm{pp}$. http://hermawankembar.blogspot. co.id/p/karya-ilmiah-upayapencegahan-dampak.html.

Kahn, R. (2010). Critical pedagogy, ecoliteracy \& planetary crisis: The Ecopedagogy Movement. New York.

Merryfield M.M, J. E. (1997). Preparing Teacher to Teach Global Perspectives. A Handbook For Teacher Educator. California: Corwin Press Inc.
Resosoedarmo Soedjiran, K. K. (1984). Pengantar Ekologi. Bandung: Remadja Karya Offset.

Soedjiran, R., M.A., K., \& Aprilani, S. (1984). Pengantar Ekologi. Bandung: Remadja Karya Offse.

Suwasono, K. M. (1994). PrinsipPrinsip Dasar Ekologi. Jakarta: Raja Grafindo Persada.

Wihardit, K. (1999). Perspektif Global. Jakarta: Universitas Terbuka.

Zoer'aini, I. D. (2012). Ekosistem, Lingkungan dan Pelestariannya. Jakarta: Bumi Aksara. 